Volume 13

Issue 3 Critical Genocide and Atrocity

Prevention Studies

$12-20-2019$

\title{
Book Review: Phenomena of Power: Authority, Domination, and Violence
}

Kerri J. Malloy

Humboldt State University

Follow this and additional works at: https://digitalcommons.usf.edu/gsp

\section{Recommended Citation}

Malloy, Kerri J. (2019) "Book Review: Phenomena of Power: Authority, Domination, and Violence,"

Genocide Studies and Prevention: An International Journal: Vol. 13: Iss. 3: 166-167.

DOI:

https://doi.org/10.5038/1911-9933.13.3.1711

Available at: https://digitalcommons.usf.edu/gsp/vol13/iss3/14

This Book Review is brought to you for free and open access by the Open Access Journals at Digital Commons @ University of South Florida. It has been accepted for inclusion in Genocide Studies and Prevention: An International Journal by an authorized editor of Digital Commons @ University of South Florida. For more information, please contact digitalcommons@usf.edu. 


\title{
Book Review: Phenomena of Power:Authority, Domination, and Violence
}

\author{
Kerri J. Malloy \\ Humboldt State University \\ Arcata, California, USA
}

Phenomena of Power: Authority, Domination, and Violence

Heinrich Popitz

New York, Columbia University Press, 2017

240 Pages; Price: $\$ 60.00$ Cloth

Reviewed by Kerri J. Malloy

Humboldt State University

German sociologist Heinrich Popitz whose work is included in the "national sociological literary canon" of Germany delves into the nature, issues, and forms of power in Phenomena of Power: Authority, Domination, and Violence. ${ }^{1}$ Initially published in 1986, in German as Phänomene der Macht, he seeks to identify the historical premises of power that informs the presumptions of society's understanding of power. In this publication, Popitz draws on lectures from over thirty years of teaching, reflections on previously published papers to expand on his work Prozesse der Machtbildung (Process of Power Formation) and provide additional chapters for this second edition.

Popitz work consists of eight chapters separated into two parts focusing on the forms of enforcement and stabilization of power. To assist the reader a chapter addressing the general conceptual framework to contextualize the analysis that follows is provided. In part one, violence, a threat to authority and the use of technical action to solidify the hold on power are analyzed as forms of the enforcement of power. In part two, Popitz describes and analyzes the processes by which power is consolidated by a few to dominate others and its institutionalization in support of the perpetuation of violence.

Chapter one serves as a primer to the monograph and provides a general framework to use as a reference for analyzing the phenomena of power. Popitz positions power as an essential "element of the human condition, fundamentally affecting the very essence of human sociability." ${ }^{2}$ Using a historical lens Popitz frames the problematization of power as a human fashioned reality that influences the structure of society. Power ubiquitously forms a transparent layer that society sees through and translates the centralized structures and institutions of everyday life. By exercising power at the upper levels of social hierarchy, limitations are placed on the freedoms of individuals in the lower strata. The ability of individuals to assert power based on their positionality in society is explored in the context of anthropological understandings of the power of asserting oneself against external forces. ${ }^{\prime 3}$ In asserting oneself, an individual is demonstrating the primacy of their power through action. The instrumentalization of power is the mobilization of punishment and rewards for oneself and others. Identifying alternatives to punishment and reward that influences the behavior of others to form the basis for authoritarian power. Power can be modified to the situation increasing and decreasing the freedoms of individuals directly and indirectly within the constraints of societal structures.

Part I examines the forms of enforcement starting with violence, the role of threats, and exploring the need for authority. Chapter two focuses on violence as a means of the enforcement of power through the infliction of harm. Those that exert violence are subjecting others to a consequence that is outside of their control. The vulnerability to violence, the anxiety, and fear that accompany it, is not something that can be ignored and is ever present in an individual's consciousness. The ultimate manifestation of violence is killing which according to Popitz shows

\footnotetext{
${ }^{1}$ Heinrich Popitz, Phenomena of Power: Authority, Domination, and Violence (New York: Columbia University Press, 2017), ix.

${ }^{2}$ Ibid., 1.

${ }^{3}$ Ibid., 9 .
} 
that "all violence has its own termination." ${ }^{4}$ In chapter three, Popitz provides a detailed analysis of instrumental power, threating and being threatened. Actions of individuals can be guided by the generation of fear through threats of the infliction of harm, whether it be physical, economic, or emotional. Being the subject of a threat or threatening behavior shapes the consciousness with which an individual determines how to react to a given situation in the presence of what is perceived as an authority figure. Building on the connection between fear and authority, Chapters four and five explore the nature of societal and individual bonds to authority. Authoritative power grows from the relationship between those who can achieve recognition, shape the perspectives, and whose acknowledgment provides the sense of self to others. ${ }^{5}$ Popitz argues, "authority is a form of superiority that, when it becomes reciprocal, can be converted into a relationship of a particular nature," in which the approval of the authority figure becomes the motivating factor for individuals. ${ }^{6}$ In chapter six Popitz brings together the preceding chapters to demonstrate how violence, threats, and authority can be employed to modify societal structures to produce actions.

Part II focuses on the process and institutionalization of the formations of power. Chapter 7 considers the question of "How does it happen that a few gain power over many?" in ways that are obvious and expected. ${ }^{7}$ Using the examples of power formation on a ship, prisoner's camp and in a boarding school, Popitz demonstrates how the capacity for organization, exclusive power, and the process by which orders are recognized provide legitimacy to those who seize power. In chapter eight, he examines the institutionalization of power in the context of the factors of its formation. Depersonalization, formalization, and integration increase as power becomes institutionalized providing stability necessary for growth and legitimacy. As power becomes increasingly centralized and routinized, its institutionalization becomes the norm within the societal structure.

Phenomena of Power lends itself for use by faculty, undergraduate and graduate students, and others who have an interest in the relationship between how society understands, complies with, challenges and institutionalizes power. For the layperson who has an interest and a general understanding of the nature and dynamics of power, this work offers an accessible means to develop further knowledge of the subject.

${ }^{4}$ Ibid., 32.

${ }^{5}$ Ibid., 93.

${ }^{6}$ Ibid., 111.

${ }^{7}$ Ibid., 131. 